\title{
Apple Stem Grooving and Citrus Tatter Leaf Capilloviruses Obtained from a Single Shoot of Japanese Pear (Pyrus serotina)
}

\author{
Nobuyuki YoshiKaWA*, Kazutoshi SASAmoto*, Manabu SAKURAdA*, \\ Tsuyoshi TAKAHASHI* and Haruo YANASE**
}

\begin{abstract}
By means of polymerase chain reactions, nucleotide sequence analyses of the $3^{\prime}$-terminal regions, and amino acid sequence analyses, two capillovirus isolates, apple stem grooving (ASGV) and citrus tatter leaf virus (CTLV) were found from virus culture V3 obtained from a single shoot of Japanese pear (Pyrus serotina). V3 was originally presumed to be a pure culture of ASGV. The two isolates that were eventually determined to be different capilloviruses were designated V3-1 and V3-2, respectively. V3-1 differed from ASGV reference isolate P-209 from apple by only 3 base substitutions in the 3 '-terminal 2611 nucleotides. V3-2 was closer to CTLV reference isolates Li-23 (95.9\% homology) and L (95.6\% homology) from lilies in the sequence of its 3 -terminal 1669 nucleotides than it was to that of ASGV isolate P-209 (89.1\% homology). In the comparison of ORF2 proteins (313 amino acids, aa) the similarity between aa sequences of V3-2 and P-209 was 94.8\%, while that between V3-2 and CTLV isolates (Li-23 and L) was $97.4 \%$. In the case of the aa sequence homology of the putative coat protein regions (237 aa), equivalent to the C-terminal region of ORF1 protein, the similarity between V3-2 and P-209 was $97.5 \%$ and was $99.2 \%$ between V3-2 and CTLV isolates (Li-23 and L). The most striking difference in aa sequence homologies was found in the ORF1 protein (277 aa) encoding ORF2 in the other frame. The similarity between V3-1 and P-209 was 99.3\%, while that between V3-2 and P-209 was $61.0 \%$. Isolate V3-2 shared $85.6 \%$ and $93.8 \%$ aa sequence homologies with Li-23 and L, respectively. Solely on the basis of comparison of nucleotide and amino acid sequences of Japanese pear isolates V3-1 and V3-2 with reference isolates, we conclude that V3-1 is almost identical to an ASGV reference isolate from apple, while V3-2 is similar to CTLV reference isolates from lilies. We recommend that CTLV be considered as a strain of ASGV.
\end{abstract}

(Received August 11, 1995 ; Accepted November 27, 1995)

Key words : capillovirus, apple stem grooving virus, citrus tatter leaf virus, Japanese pear.

\section{INTRODUCTION}

Apple stem grooving capillovirus (ASGV) is the type member of genus Capillovirus ${ }^{5}$ and distributed worldwide in apple trees ${ }^{4)}$. In Japan, ASGV has been reported to be isolated from apple ${ }^{14)}$, pear ${ }^{9)}$, Japanese pear ${ }^{12)}$ and Japanese apricot imported from China ${ }^{11}$. ASGV has a coat protein of $M_{\mathrm{r}} 27,000(27 \mathrm{~K})$ and a ssRNA of $M_{\mathrm{r}}$ $2.30 \times 10^{6}{ }^{14}$. . The complete nucleotide sequence of the ASGV genome was reported for an isolate (P-209) from an apple tree ${ }^{17}$. The genome consists of 6496 nucleotides excluding the $3^{\prime}$ poly $(\mathrm{A})$ tail and contains two overlapping open reading frames (ORFs). ORF1 encodes a $241 \mathrm{~K}$ polyprotein containing consensus motifs of methyltransferase, helicase, RNA polymerase and a coat protein in the C-terminal region ${ }^{17}$. ORF2 encodes a $36 \mathrm{~K}$ protein which may act as a cell to cell movement protein ${ }^{16)}$.
Recently, the sequences of the $3^{\prime}$-terminal region of RNA of citrus tatter leaf virus (CTLV), another member of genus Capillovirus, were reported for two isolates (Li-23 and $\mathrm{L}$ ) from lilies ${ }^{7,16)}$. The genome organization in the $3^{\prime}$-terminal region of CTLV-RNA is in perfect agreement with that of the ASGV genome. The sequence of the 3 '-terminal 2956 nucleotides, excluding poly(A) tail, of the CTLV (isolate Li-23) genome shows $86.1 \%$ identity to that of the ASGV ${ }^{16)}$. Amino acid sequence identities of ORFs 1 and 2 between both viruses are 86.1\% and $97.3 \%$, respectively ${ }^{16)}$. Both viruses also have similar biological and serological properties. The results imply that CTLV may be regarded as a strain of ASGV.

In this study, we investigated the nucleotide sequence of the $3^{\prime}$-terminal region of ASGV (V-3) from Japanese pear and compared the nucleotide sequence and the amino acid sequence coded by ORFs 1 and 2 with those of ASGV (P-209) from apple and two isolates of CTLV

* Faculty of Agriculture, Iwate University, Morioka 020, Japan

** Fruit Tree Research Station, Tsukuba 305, Japan 
from lilies.

\section{MATERIALS AND METHODS}

Virus. ASGV (culture V-3), originally isolated from Japanese pear ${ }^{12)}$, ASGV (isolate P-209) from apple $^{14)}$ and CTLV (isolate Li-23) from lily ${ }^{1)}$ were propagated in Chenopodium quinoa. Virus (V-3) was purified from infected $C$. quinoa leaves and viral RNA was extracted from purified virus by the SDS-phenol method as described previously ${ }^{15}$.

Polymerase chain reaction. Total RNAs were extracted from $100 \mathrm{mg}$ of $C$. quinoa leaves inoculated with ASGV (V-3), ASGV (P-209) or CTLV (Li-23) according to the method of Verwoerd et al. $(1989)^{13)}$. RNA was also prepared directly from freeze-dried leaves $(10 \mathrm{mg})$ of $C$. quinoa infected with ASGV (V-3) which had been stored at the Fruit Tree Research Station. RNA was finally dissolved in $0.1 \mathrm{ml}$ of sterile distilled water.

Several primers were designed for amplifications of the 3'-terminal regions of ASGV (V-3) genome on the basis of the sequences of ASGV (P-209)- and CTLV (Li-23)-genomes ${ }^{16,17)}$. The locations and sequences of primers used in this study are shown in Fig. 1 and Table 1. First strand cDNA synthesis and polymerase chain reaction (PCR) was conducted as follows: a reaction mixture $(50 \mu 1)$ containing $10 \mu \mathrm{l}$ of $5 \times$ first strand buffer (250 mM Tris, pH 8.3, $375 \mathrm{mM} \mathrm{KCl,} 15 \mathrm{mM} \mathrm{MgCl}_{2}, 50$ mM DTT), $10 \mu \mathrm{l}$ of $2.5 \mathrm{mM}$ dNTPs, $2 \mu \mathrm{l}$ of primers [ASCT-3'(-) or ASCT-PC(-) ; $10 \mu \mathrm{M}$ ] (Table 1), $5 \mu 1$ of total RNA, $18.5 \mu 1$ of distilled water and $2.5 \mu \mathrm{l}$ of M-MLV reverse transcriptase (200 units/ $\mu 1$, United State Biochemical Corporation) was incubated at $37^{\circ} \mathrm{C}$ for $1 \mathrm{hr}$. Aliquots $(10 \mu \mathrm{l})$ of the resulting cDNA solution were transferred to a tube containing $26.8 \mu 1$ of distilled water, $5 \mu \mathrm{l}$ of $10 \times$ Taq buffer $(100 \mathrm{mM}$ Tris, $\mathrm{pH} 8.3,500$ $\mathrm{mM} \mathrm{KCl}, 15 \mathrm{mM} \mathrm{MgCl}_{2}, 0.01 \%$ gelatin), $4 \mu 1$ of $2.5 \mathrm{mM}$ dNTPs, $2 \mu 1$ of primer 1 [ASCT-3' $(-)$ or ASCT$\mathrm{PC}(-) ; 10 \mu \mathrm{M}$ ], $2 \mu \mathrm{l}$ of primer 2 [ASGV-ON2(+), CTLV-ON $(+)$, ASGV-CP2 $(+)$ or ASGV-ORF2P $(+)$; $10 \mu \mathrm{M}$ ] (Table 1) and $0.25 \mu \mathrm{l}$ of Taq DNA polymerase (5 units/ $\mu 1$, Takara). PCRs were performed for 30 cycles with the program $\left(95^{\circ} \mathrm{C}, 1 \mathrm{~min} ; 52^{\circ} \mathrm{C}, 1 \mathrm{~min} ; 72^{\circ} \mathrm{C}, 1 \mathrm{~min}\right)$ using ZYMOREACTOR II (ATTO). Aliquots $(5 \mu 1)$ of the reaction mixture were analyzed on a $1 \%$ agarose gel containing $0.5 \mu \mathrm{g} / \mathrm{ml}$ of ethidium bromide. The remnants were extracted with an equal volume of phenol/ chloroform $(1: 1)$ and the amplified fragments were precipitated with ethanol, washed with $70 \%$ ethanol and dissolved in water.
cDNA cloning. The PCR products described above were ligated to p T7 blue T-Vector (Novagen) and used to transform Escherichia coli JM109. In the case of $\mathrm{V}-3$, first and second strand cDNAs were prepared from purified viral RNA using oligo (dT) primer described before $^{17)}$. The dsDNAs were ligated to the SmaI site of Bluescript $\mathrm{KS}^{+}$and used to transform competent $E$. coli JM109.

Nucleotide sequencing. The nucleotide sequences of cDNA clones were determined with an Applied Biosystems 373A or a Hitachi 5500 DNA sequencer using the dideoxynucleotide method $^{8)}$ and Taq polymerase. For nucleotide sequencing of cDNA clones derived from PCR products, at least 3 clones were used for the determination of the nucleotide sequence of a given region. For nucleotide sequencing of isolate $\mathrm{V}-3,9$ overlapping cDNA clones (nucleotide sizes 0.5 to $2.6 \mathrm{kbp}$ ) were used to determine the $3^{\prime}$-terminal $2.6 \mathrm{~kb}$ nucleotide sequence. Every base was determined by sequencing at least two independent clones or by sequencing twice from a single clone. Sequence data were collected, assembled and analyzed using the program GENETYX (Software Development Co., Ltd.).

\section{RESULTS}

\section{Amplifications of the 3'-terminal region of ASGV (culture V-3) genome by polymerase chain reaction}

At first we tried to amplify genome fragments of ASGV (V-3) in RNA samples extracted from infected $C$. quinoa by PCR using several primers (Fig. 1 and Table 1). Primers, ASGV-ON2(+) and CTLV-ON $(+)$, were designed for specific amplifications of ASGV- and CTLV-genomes, respectively. We anticipated that the other primers would anneal with both virus genomes. As expected, use of the primer pair [ASGV-ON2 $(+)$ and ASCT-3'(-)] allowed the fragments with an expected size $(c a .0 .6 \mathrm{kbp})$ to amplify in samples from ASGV (P-209)-infected leaves, but not from CTLV (Li-23)infected ones (Fig. 2, lanes 1 and 5). Moreover, by use of the primer pair [CTLV-ON $(+)$ and ASCT-3'(-)], fragments with an expected size $(c a .1 .1 \mathrm{kbp})$ were amplified in samples from CTLV-infected leaves, but not from ASGV-infected ones (Fig. 2, lanes 2 and 6). When RNA samples from ASGV (V-3)-infected leaves were used as templates, the amplification of fragments with expected sizes of $0.6 \mathrm{kbp}$ occurred for a primer pair [ASGV$\mathrm{ON} 2(+)$ and ASCT $\left.-3^{\prime}(-)\right]$ and $1.1 \mathrm{kbp}$ for a primer pair [CTLV-ON $(+)$ and ASCT-3'(-)] (Fig. 2, lanes 3 and 4).

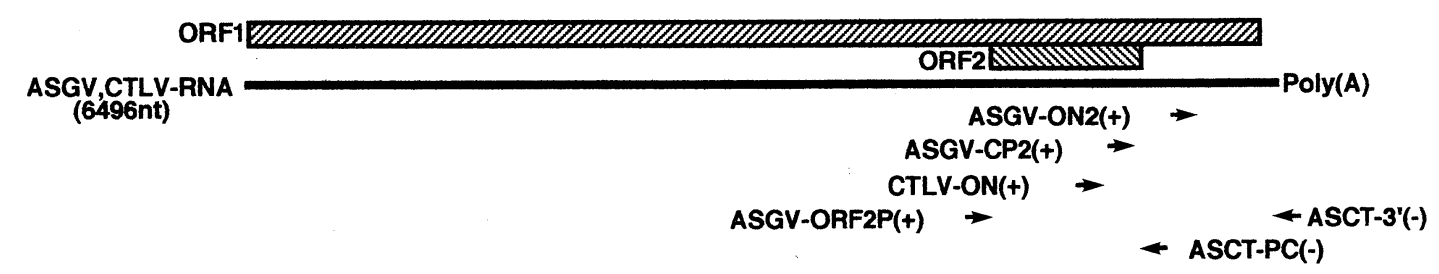

Fig. 1. Locations of primers used in this study for the PCR amplification of ASGV-and CTLV-genomes. 
Table 1. Primers used for the PCR amplification of the 3 'terminal regions of apple stem grooving virus (culture V-3) genome

\begin{tabular}{|c|c|}
\hline Primers $^{\text {a) }}$ & Sequences $\left(5^{\prime}-3^{\prime}\right)^{\mathrm{b})}$ \\
\hline \multicolumn{2}{|l|}{ forward } \\
\hline ASGV-ON2(+) & ${ }^{5929} \mathrm{GAAGGGGAGACTGACGAAGG}{ }^{5948}$ \\
\hline ASGV-CP2(+) & ${ }^{5641}$ ATGAGTTTGGAAGACGTGCT ${ }^{5660}$ \\
\hline CTLV-ON(+) & ${ }^{5347}$ ATTCAGCTCGTTTCTTGGAG ${ }^{5366}$ \\
\hline $\begin{array}{l}\text { ASGV- } \\
\quad \text { ORF2P(+) }\end{array}$ & ${ }^{4788}$ ATGGCTATCGTCAACGTCAA ${ }^{4807}$ \\
\hline \multicolumn{2}{|l|}{ reverse } \\
\hline $\operatorname{ASCT}-3^{\prime}(-)$ & ${ }^{6496}$ AGAGTGGACAAACTATAGAC ${ }^{6477}$ \\
\hline ASCT-PC(-) & ${ }^{5734}$ TCAGAAGTTCCTTTGCCGGG ${ }^{5715}$ \\
\hline
\end{tabular}

a) Primers were designed on the basis of the nucleotide sequences of the genomes of ASGV (P-209) ${ }^{16)}$ and CTLV $(\mathrm{Li}-23)^{15)}$

b) Figures indicate the nucleotide positions in the genome of ASGV (P-209) ${ }^{16)}$.

\section{Evidence for the presence of two capilloviruses in culture V-3 of ASGV}

We determined the nucleotide sequences of $\mathrm{CDNA}$ clones from purified ASGV (isolate V-3). The sequence of the $3^{\prime}$-terminal 2611 nucleotides, excluding the poly(A) tail, of the V-3 genome is almost identical to that of the corresponding region of P-209 genome from apple. The difference in the $3^{\prime}$-terminal 2611 nucleotide sequence between both isolates is only three base substitutions ; C in nt position 5249 of P-209 changes to $\mathrm{A}$ in $\mathrm{V}-3$, G (position 5641 of P-209) to A (V-3) and G (position 5968 of $\mathrm{P}-209)$ to $\mathrm{A}(\mathrm{V}-3)$. $\Lambda 11$ three substitutions lead to changes in their coded amino acids (proline to glutamine, alanine to threonine and glycine to glutamic acids, respectively) in ORF1. An isolate having this nucleotide sequence was designated V3-1.

In the following experiments, we determined the nucleotide sequences of cDNA clones derived from PCR products of $\mathrm{V}-3$. Four clones of the $0.6 \mathrm{kbp}$ products which were amplified by a primer pair [ASGV-ON2(+) and ASCT-3' $(-)$ ] were used for the determination of nucleotide sequences and all clones were shown to be identical. The nucleotide sequence of the $0.6 \mathrm{kbp}$ products was found to be completely identical to the $3^{\prime}$ terminal $0.6 \mathrm{~kb}$ nucleotide sequence of V3-1.

Nine clones of the $0.8 \mathrm{kbp}$ products amplified by a primer pair [ASGV-CP2 $(+)$ and ASCT-3'(-)], four clones of the $1.1 \mathrm{kbp}$ products by a primer pair [CTLV$\mathrm{ON}(+)$ and ASCT-3' $(-)]$ and three clones of the 1.0 kbp products by a primer pair [ASGV-ORF $2 \mathrm{P}(+)$ and ASCT-PC $(-)]$ were also sequenced. There were no sequence variations among clones of each PCR product, and overlapping regions among these three products were found to have identical nucleotide sequences. Unexpectedly, the assembled 3'-terminal 1669 nucleotide sequence (this isolate was designated V3-2) is not consistent with that of the corresponding region of V3-1 and the similarity between V3-1 and V3-2 was 89.1\% (Fig. 3

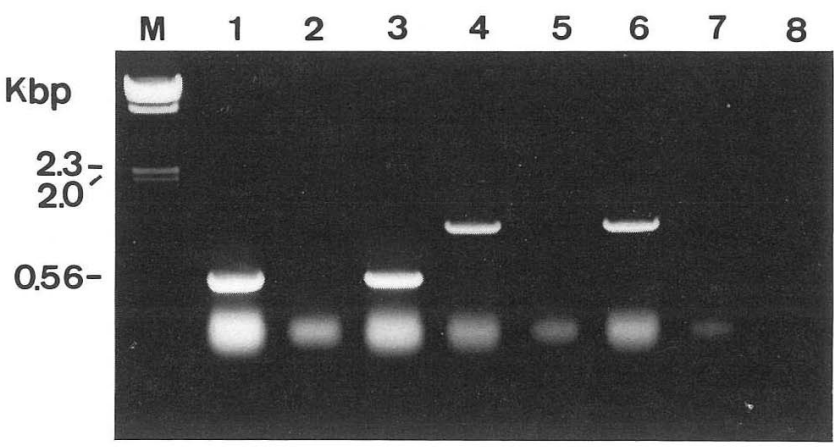

Fig. 2. Agarose gel electrophoresis of DNAs amplified by a polymerase chain reaction from $C$. quinoa leaves infected with ASGV (P-209), ASGV (V-3) or CTLV (Li-23). Lane M, lamda DNA digested with HindIII, lanes 1 and 2, ASGV (P-209), lanes 3 and 4, ASGV (V-3), lanes 5 and 6, CTLV (Li-23), lanes 7 and 8, healthy C. quinoa leaves. Lanes 1, 3, 5 and 7 and lanes 2, 4, 6 and 8 were the products amplified by using the primer pair $\left[\mathrm{ASGV}-\mathrm{ON} 2(+)\right.$ and $\left.\mathrm{ASCT}-3^{\prime}(-)\right]$ and the primer pair [CTLV-ON $(+)$ and ASCT-3'(-)], respectively.

and Table 2). The nucleotide sequence of V3-2 is rather similar to those of CTLV genomes and the homologies with those of isolates $\mathrm{Li}-23^{16)}$ and $\mathrm{L}^{7)}$ are $95.9 \%$ and $95.6 \%$, respectively (Table 2 ). The results indicate that a virus culture $\mathrm{V}-3$ of $\mathrm{ASGV}$ is a mixture of two capilloviruses, one is almost identical to ASGV (P-209) from apple and another is similar to CTLV from lily.

Comparisons of amino acid sequences encoded by ORFs 1 and 2 among isolates of $A S G V$ and CTLV

The 3 '-terminal nucleotide sequences of V3-1 and V3-2 have neither deletion or insertion of bases compared with the corresponding regions of ASGV (P-209) and CTLVs (Li-23 and L) and so their coding regions (a part of ORF1 and ORF2) are completely consistent with those of ASGV and CTLV. We compared the amino acid sequences of a $36 \mathrm{~K}$ protein (320 amino acids; aa) encoded by ORF2 (nt positions 4788 to 5750 in Fig. 3), a putative coat protein (237 aa) equivalent to the Cterminal region of ORF1 (nt positions 5641 to 6354 in Fig. 3) and a protein region of ORF1 (284 aa) which encodes ORF2 in the other frame (nt positions 4789 to 5640 in Fig. 3) among isolates of ASGV and CTLV. As shown in Fig. 3, most of the base substitutions found among isolates of ASGV and CTLV were nonsense mutations for the $36 \mathrm{~K}$ protein encoded by ORF2 and for a putative coat protein region. The amino acid sequence of a $36 \mathrm{~K}$ protein was highly conserved among isolates of ASGV and CTLV and the similarity was $94.8 \%$ between V3-2 and P-209 and 97.4\% between V3-2 and CTLV isolates (Table 3). The similarity of amino acid sequences of the putative coat protein was also high among isolates of ASGV and CTLV (Table 4). The amino acid sequence of V3-2 coat protein is closer to 


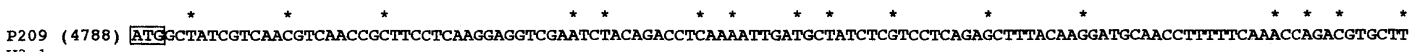

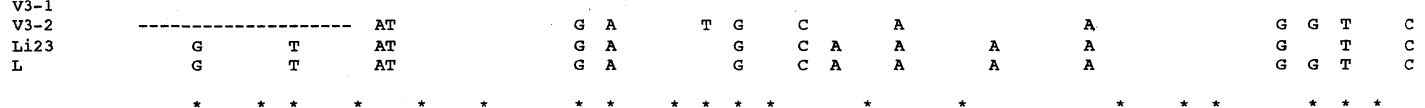

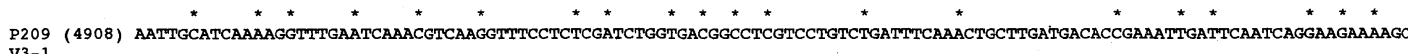

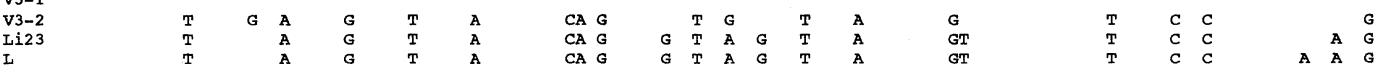

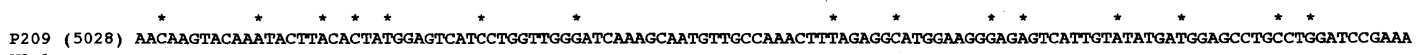

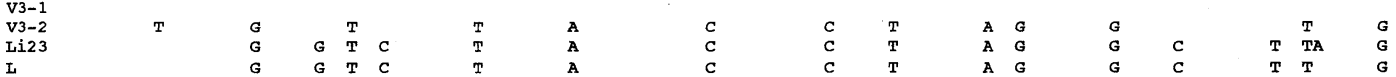
G P209 (5148) AGAGGCCACATTTGCTCGTATCTPTTCAAGTPTGAGTCTGACTGTTGCTACTTTGGTCTCAGGCCAGAGCACTGTTTGTCTACCACAGACGCAAATTTGGCCAAAAGGTITAGATTTCGT

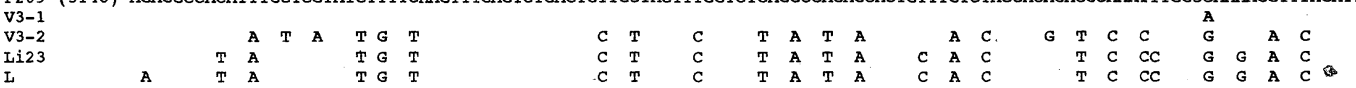

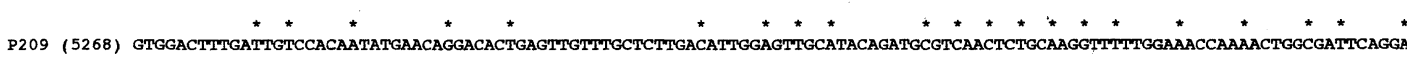

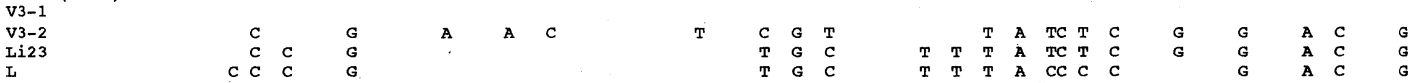
* * * * * * * * * * * * * * * * **** * * * *

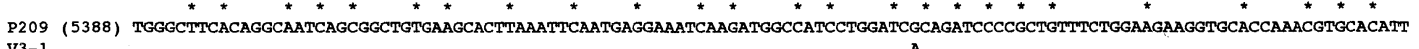

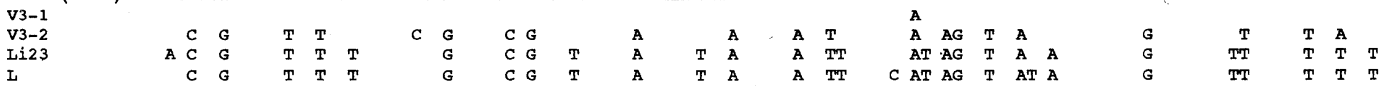
* * * * * * * * * * * * * * P209 (5508) GAAAAGAGATTGTTCAGAGGTGACAAGGTTAGAAGGTCACGCTCAATTTCCGCTAAAAGGGGGCCAAACTCAAGGGTGCAAGAAAAGAGAGGATPTAGGTCCCTCTCGGCTAGAATTGA

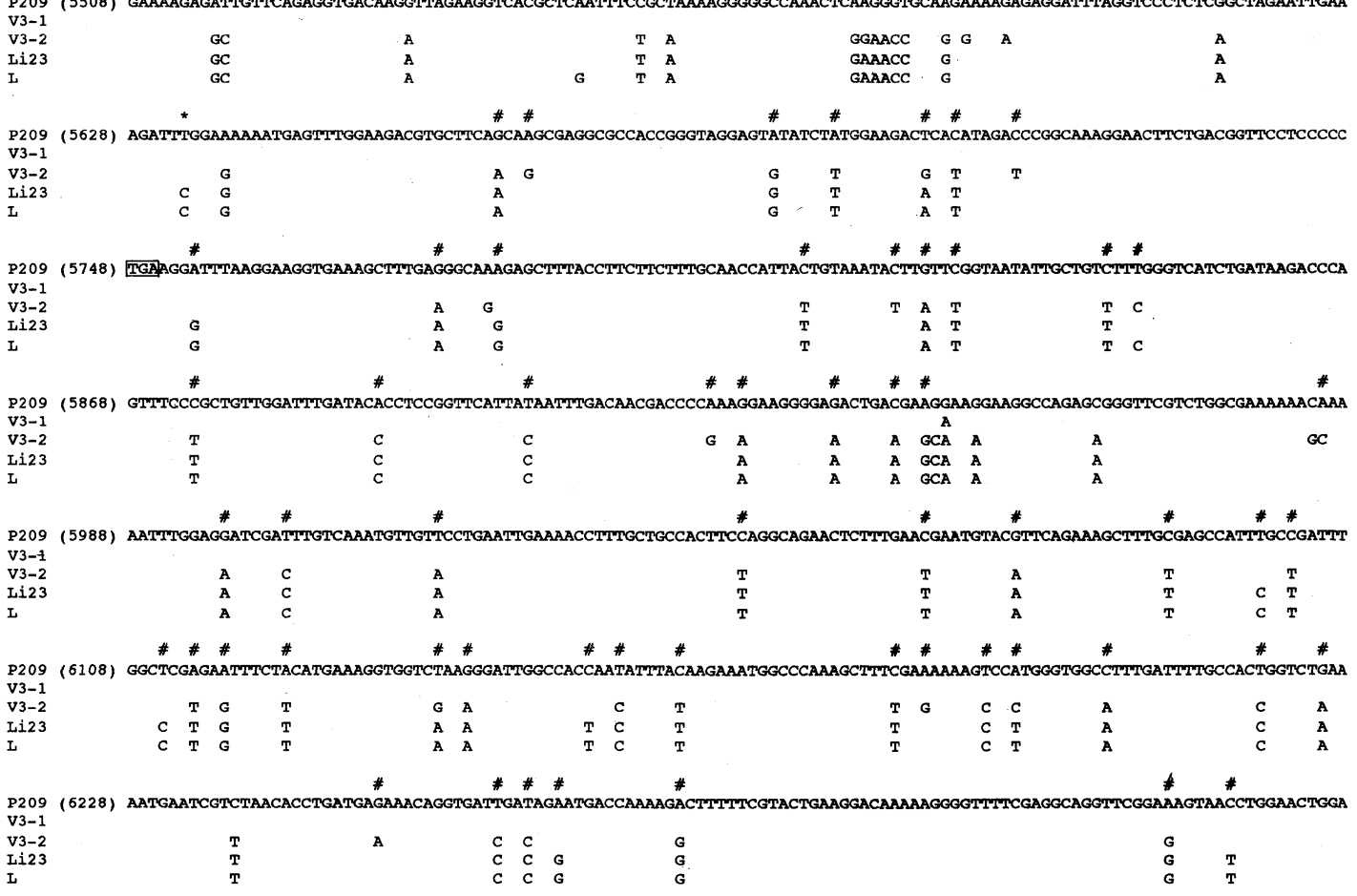

P209 (6348) GGGT AAGGAGTCGTGTGAAATTCCGCAAACTTGGTCGCGGTCTTGCAGGTTGACATGCCTGCCTTTATACTPAATTAAAGGGTCCCCCGGTPTCTGAGCATTTCCGGGTTAGTGTGGT v3-1

$\mathrm{V} 3-2$
$\mathrm{Li} 23$

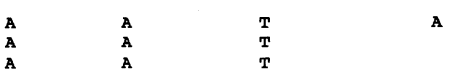

P209 (6468) TTPTCTAGAGTCTAGAGTPTGTCCACTCT

V3-1

Li23

Fig. 3. Nucleotide sequence alignment of the $3^{\prime}$-terminal 1709 bases of the genomes of ASGV (isolates P-209, V3-1 and V3-2) and CTLV (isolates Li-23 and L). Bases that differ from P-209 are shown below the P-209 sequence. Figures on the left side are the nucleotide positions of P-209 genomes and dotted lines indicate the positions of primers [ASGV-ORF2P(+) and ASCT-3'(-)] used for amplification of the V3-2 genome. Initiation codon of a ORF2 protein and termination codons of ORF2 and ORF1 proteins are boxed. Asterisks $\left({ }^{*}\right)$ and pound signs (\#) above the nucleotide sequences are the positions of base substitutions which do not change amino acid sequences of the ORF2 protein and the putative coat protein, respectively. The nucleotide sequences were drawn from the papers by Yoshikawa et al. ${ }^{16,17)}$ for P-209 and Li-23 and Ohira et $a l .{ }^{7)}$ for L. 
Table 2. Percentage of sequence similarity of the $3^{\prime}$ terminal 1709 nucleotides among apple stem grooving virus- and citrus tatter leaf virusgenomes $^{\text {a) }}$

\begin{tabular}{lrrrrr}
\hline \hline & $\begin{array}{c}\text { ASGV } \\
(\mathrm{P}-209)\end{array}$ & $\begin{array}{r}\text { ASGV } \\
\text { (V3-1) }\end{array}$ & $\begin{array}{r}\text { ASGV } \\
\text { (V3-2) }\end{array}$ & $\begin{array}{r}\text { CTLV } \\
(\mathrm{Li}-23)\end{array}$ & $\begin{array}{c}\text { CTLV } \\
\text { (L) }\end{array}$ \\
\hline ASGV (P-209) $)^{\mathrm{b}}$ & 100.0 & 99.8 & 89.0 & 88.5 & 88.2 \\
ASGV (V3-1) & & 100.0 & 89.1 & 88.7 & 88.4 \\
ASGV (V3-2) & & & 100.0 & 95.9 & 95.6 \\
CTLV (Li-23) & & & & 100.0 & 99.1 \\
CTLV (L) & & & & & 100.0 \\
\hline
\end{tabular}

a) For ASGV (V3-2), the sequence of 1669 nucleotides excluding two primer sequences at the $5^{\prime}$ - and $3^{\prime}$ terminal regions was compared.

b) The nucleotide sequences compared had been presented in the papers by Yoshikawa et al. ${ }^{17)}$ for ASGV (P-209), Yoshikawa et al. ${ }^{16)}$ for CTLV (Li-23) and Ohira et al. ${ }^{7)}$ for CTLV (L).

Table 3. Percentage of amino acid sequence similarity of an ORF2 protein (320 amino acids) among isolates of apple stem grooving virus and citrus tatter leaf virus

\begin{tabular}{lcrrrr}
\hline \hline & $\begin{array}{c}\text { ASGV } \\
(\mathrm{P}-209)\end{array}$ & $\begin{array}{r}\text { ASGV } \\
\text { (V3-1) }\end{array}$ & $\begin{array}{c}\text { ASGV } \\
\text { (V3-2) }\end{array}$ & $\begin{array}{r}\text { CTLV } \\
(\mathrm{Li}-23)\end{array}$ & $\begin{array}{c}\text { CTLV } \\
\text { (L) }\end{array}$ \\
\hline ASGV (P-209) & 100.0 & 99.7 & 94.8 & 94.7 & 94.7 \\
ASGV (V3-1) & & 100.0 & 94.9 & 95.0 & 95.0 \\
ASGV (V3-2) & & & 100.0 & 97.4 & 97.4 \\
CTLV (Li-23) & & & & 100.0 & 98.8 \\
CTLV (L) & & & & & 100.0 \\
\hline
\end{tabular}

a) For ASGV (V3-2), the sequence of 313 amino acids (aa) excluding N-terminal 7 aa derived from a primer sequence was compared.

that of CTLV (99.2\%) than to ASGV (P-209) (97.5\%). The most striking difference that we observed among isolates of ASGV and CTLV was in the amino acid sequence of an ORF1 protein region encoding ORF2 in the other frame (Table 5). The similarity was $99.3 \%$ between P-209 and V3-1, 61.0\% between P-209 and V3-2 and $85.6 \%$ between V3-2 and Li-23. Comparison of amino acid sequences described above also indicate that V3-1 is almost identical to ASGV (P-209) from apple and V3-2 is closer to CTLV than to ASGV.

\section{DISCUSSION}

The results of PCR amplifications and nucleotide and amino acid sequence analyses of the genome of ASGV (culture V-3) described above indicate that V-3 contains two capilloviruses (designated V3-1 and V3-2). Fragments of both V3-1 and V3-2 were amplified from RNA samples directly extracted from freeze-dried materials stored at the Fruit Tree Research Station, Tsukuba, excluding the possibility of contamination in the greenhouse during this study. It is very probable that V-3 is a
Table 4. Percentage of amino acid sequence similarity of a putative coat protein region (237 amino acids) of an ORF1 protein among isolates of apple stem grooving virus and citrus tatter leaf virus ${ }^{a)}$

\begin{tabular}{lcrrrr}
\hline \hline & $\begin{array}{c}\text { ASGV } \\
\text { (P-209) }\end{array}$ & $\begin{array}{r}\text { ASGV } \\
\text { (V3-1) }\end{array}$ & $\begin{array}{r}\text { ASGV } \\
\text { (V3-2) }\end{array}$ & $\begin{array}{r}\text { CTLV } \\
\text { (Li-23) }\end{array}$ & $\begin{array}{c}\text { CTLV } \\
\text { (L) }\end{array}$ \\
\hline ASGV (P-209) & 100.0 & 99.6 & 97.5 & 98.3 & 98.3 \\
ASGV (V3-1) & & 100.0 & 97.5 & 98.3 & 98.3 \\
ASGV (V3-2) & & & 100.0 & 99.2 & 99.2 \\
CTLV (Li-23) & & & & 100.0 & 100.0 \\
CTLV (L) & & & & & 100.0 \\
\hline
\end{tabular}

a) The putative coat protein region is equivalent to the amino acid positions 1869-2105 of ASGV ORF1 $\operatorname{protein}^{16)}$.

Table 5. Percentage of amino acid sequence similarity of an ORF1 protein region (284 amino acids) encoding ORF2 in the other frame among isolates of apple stem grooving virus and citrus tatter leaf virus ${ }^{\text {a) }}$

\begin{tabular}{lcrrrr}
\hline \hline & $\begin{array}{c}\text { ASGV } \\
(\mathrm{P}-209)\end{array}$ & $\begin{array}{r}\text { ASGV } \\
\text { (V3-1) }\end{array}$ & $\begin{array}{c}\left.\text { ASGV }^{\mathrm{b}}\right) \\
(\mathrm{V} 3-2)\end{array}$ & $\begin{array}{c}\text { CTLV } \\
(\mathrm{Li}-23)\end{array}$ & $\begin{array}{c}\text { CTLV } \\
(\mathrm{L})\end{array}$ \\
\hline ASGV (P-209) & 100.0 & 99.3 & 61.0 & 58.5 & 56.7 \\
ASGV (V3-1) & & 100.0 & 61.0 & 59.5 & 56.7 \\
ASGV (V3-2) & & & 100.0 & 85.6 & 93.8 \\
CTLV (Li-23) & & & & 100.0 & 97.5 \\
CTLV (L) & & & & & 100.0 \\
\hline
\end{tabular}

a) The protein region compared is equivalent to the amino acid positions $1585-1868$ of ASGV ORF1 protein ${ }^{16}$.

b) For ASGV (V3-2), the sequence of 277 aa excluding $\mathrm{N}$-terminal 7 aa derived from a primer sequence was compared.

mixture of two capilloviruses because the virus has been latently infecting fruit trees such as apple and pear for a long time and so several isolates and/or strains may possibly exist in a single tree.

In our experiments, 9 cDNA clones derived from purified viral RNA of $\mathrm{V}-3$ all have the nucleotide sequence of V3-1. This result is not consistent with those obtained by PCR amplifications in which fragments representing the nucleotide sequences of either V3-1 or V3-2 were amplified from the same RNA sample. One possible explanation of this discrepancy is that the titer of V3-1 was higher than that of V3-2 in infected leaves used for virus purification. Two forward primers $[\mathrm{ASGV}-\mathrm{ON}(+)$ and CTLV-ON $(+)]$ were designed for specific amplifications of ASGV (P-209) and CTLV (Li23), respectively. As shown in Fig. 1, use of the primer pair [ASGV-ON2(+) and ASCT-3'(-)] allowed the amplification of the expected fragments $(0.6 \mathrm{kbp})$ of P-209 and V3-1, while the primer pair [CTLV-ON $(+)$ and ASCT $\left.-3^{\prime}(-)\right]$ amplified the fragments $(1.1 \mathrm{kbp})$ of $\mathrm{Li}-23$ and V3-2. Two other forward primers [ASGV$\mathrm{CP} 2(+)$ and $\mathrm{ASGV}-\mathrm{ORF} 2 \mathrm{P}(+)]$ were expected to an- 
neal to both V3-1 and V3-2 genomes. However, 9 cDNA clones from fragments $(0.8 \mathrm{kbp})$ amplified by a primer pair [ASGV-CP2 $(+)$ and ASCT-3' $(-)$ ] and three clones from fragments $(1.0 \mathrm{kbp})$ by a primer pair [ASGV$\mathrm{ORF} 2 \mathrm{P}(+)$ and ASCT-PC( $(-)]$ had the nucleotide sequence of V3-2. We do not know why these primer pairs only allowed amplification of the V3-2 fragments, although clones containing V3-1 fragments may be found if more clones are sequenced.

The data presented in this paper have some implications for the classification of capillovirus. ASGV and CTLV are presently regarded as distinct viruses. In fact, ASGV has been naturally isolated from Malus ${ }^{14)}$, Pyrus $^{9,12)}$ and Prunus spp. ${ }^{11)}$ and, on the other hand, CTLV from Citrus spp. ${ }^{6,10)}$ and lily ${ }^{1,7)}$. However, both viruses have similar particle structures and biological (experimental host ranges and symptoms on indicator plants) and serological properties ${ }^{1,3,6,14,16)}$. Recently, Iwanami et $a l .{ }^{2)}$ demonstrated that ASGV (V-3) could infect Rusk citrange and induce symptoms similar to those induced by CTLV infection. From the results of our present study, we propose that CTLV be regarded as a strain of ASGV.

We would like to thank Dr. R.H. Converse for his critical reading of the manuscript.

\section{Literature cited}

1. Inouye, N., Maeda, T. and Mitsuhata, K. (1979). Citrus tatter leaf virus isolated from lily. Ann. Phytopathol. Soc. Jpn. 45 : 712-720.

2. Iwanami, T., Kano, T. and Koizumi, M. (1991). Ann. Phytopathol. Soc. Jpn. 57 : 74 (Abstr. in Japanese).

3. Kawai, A., Kobayashi, T., Tsukamoto, T., Dai, K., Kimishima, E., Kimura, S. and Goto, M. (1991). Production of monoclonal antibodies against citrus tatter leaf virus. Res. Bull. Pl. Prot. Serv. Japan 27 : 55-60.

4. Lister, R.M. (1970). Apple stem grooving virus. CMI/ AAB Descriptions of Plant Viruses, No. 31.

5. Murphy, F.A., Fauquet, C.M., Bishop, D.H.L., Ghabrial, S.A., Jarvis, A.W., Martelli, G.P., Mayo, M.A. and Summers, M.D. eds. (1995). Virus taxonomy. Sixth Report of the International Committee on Taxonomy of Viruses, Arch. Virol. Suppl. 10, 586 pp.

6. Nishio, T., Kawai, A., Takahashi, T., Namba, S. and Yamashita, S. (1989). Purification and properties of citrus tatter leaf virus. Ann. Phytopathol. Soc. Jpn. 55 : 254-258.

7. Ohira, K., Ito, T., Kawai, A., Namba, S., Kusumi, T. and Tsuchizaki, T. (1994). Nucleotide sequence of the $3^{\prime}$ terminal region of citrus tatter leaf virus RNA. Virus Genes 8: 169-172.

8. Sanger, F., Nicklen, S. and Coulson, A.R. (1977). DNA sequencing with chain-terminating inhibitors. Proc. Natl. Acad. Sci., USA 74 : 5463-5467.

9. Sawamura, K., Yamashita, K. and Arai, M. (1988). An apple stem grooving virus strain isolated from European pear (Pyrus communis). Bull. Fac. Agric. Hirosaki Univ. $50: 22-26$.
10. Semancik, J.S. and Weathers, L.G. (1965). Partial purification of a mechanically transmissible virus associated with tatter leaf of citrus. Phytopathology 55 : 1354-1358.

11. Takahashi, T., Saito, N., Goto, M., Kawai, A., Namba, S. and Yamashita, S. (1990). Apple stem grooving virus isolated from Japanese apricot (Prunus mume) imported from China. Res. Bull. Pl. Prot. Serv. Japan 26 : 15-21.

12. Takahashi, K. (1983). Ann. Phytopathol. Soc. Jpn. 49 : 432 (Abstr. in Japanese).

13. Verwoerd, T.C., Dekker, B.M.M. and Hoekema, A. (1989). A small-scale procedure for the rapid isolation of plant RNAs. Nucl. Acids Res. 17 : 2362.

14. Yanase, H. (1974). Studies on apple latent viruses in Japan. Bull. Fruit Tree Res. Sta. Japan, Ser. C1, 47-109.

15. Yoshikawa, N. and Takahashi, T. (1988). Properties of RNAs and proteins of apple stem grooving and apple chlorotic leaf spot viruses. J. Gen. Virol. 69 : 241-245.

16. Yoshikawa, N., Imaizumi, M., Takahashi, T. and Inouye, N. (1993). Striking similarities between the nucleotide sequence and genome organization of citrus tatter leaf and apple stem grooving capilloviruses. J. Gen. Virol. 74 : 2743-2747.

17. Yoshikawa, N., Sasaki, E., Kato, M. and Takahashi, T. (1992). The nucleotide sequence of apple stem grooving capillovirus genome. Virology 191 : 98-105.

\section{和 文 摘 要}

吉川信幸・笹本和稔・桜田 学・高橋 壮・柳瀬春夫 : 二ホン ナシから分離されたリンゴステムグルービングウイルスとカン キツタターリーフウイルス

ニホンナシから分離され, リンゴステムグルービングウイル ス (ASGV) のV-3 株と呼ばれていたウイルスに関して,ゲノム の $3^{\prime}$ 末端領域の PCR による増幅, 塩基配列およびコードされる タンパク質のアミノ酸配列の解析を行った結果，V-3 株には 2 種類のカピロウイルス（分離株 V3-1 とV3-2）が含まれている ことが明らかになった。V3-1 は，ゲノムの 3 ”末端 2661 塩基に おいて, ASGV のリンゴ分離株 (P-209) と 3 塩基の置換が認め られるのみであった。一方，V3-2 は，3’末端 1669 塩基におい て, P-209 とは 89.1\%の相同性であるのに対し, ユリから分離さ れた CTLVの 2 分離株, $\mathrm{Li}-23$ と L とは, それぞれ $95.9 \%$ と 95.6\% の相同性であった。ゲノムがコードする ORF2 のアミノ 酸 (313 アミノ酸； aa）配列の比較では, V3-2 と P-209 間で $94.8 \%, V 3-2$ と CTLV (Li-23 と L) 間で $97.4 \%$ の相同性が認め られ, ORF1 の外被タンパク質 $(\mathrm{CP})$ 領域 (237aa) のアミノ酸 配列では, V3-2 と P-209間で 97.5\%, V3-2 と CTLV (Li-23 と L) 間で $99.2 \%$ 相同性であった。また ORF1 の CP 領域の上流 側 277aa（別のフレームで ORF2 をコードしている領域）のア ミノ酸配列の比較では，V3-1 と P-209間で $99.3 \%$ 相同性であ るのに対して, V3-2 と P-209間では 61.0\%で, V3-2 と CTLV の 2 分離株 Li-23 と L 間では, それぞれ $85.6 \%$ と $93.8 \%$ の相同 性が認められた。以上から, V3-1 は ASGV のリンゴ分離株とほ とんど同一であり，V3-2 はユリから分離された CTLV に類似 していることが明らかになった。現在, ASGV と CTLVは, 主 に分離される原宿主の違いから別種のウイルスとして扱われて いるが，両ウイルス間でゲノムの塩基配列やコードされるタン パク質のアミノ酸配列に高い相同性が認められること, また生 物学的および血清学的にも区別できないことから, CTLVは ASGV の系統であると提唱したい。 